\title{
Possibility of Heat Pump use in Hot Water Supply Systems
}

\author{
Tatyana Babak, Neven Duic ${ }^{2}$, Gennadiy Khavin ${ }^{3}$, Stanislav Boldyryev ${ }^{* 4}$, \\ Goran Krajačic ${ }^{5}$ \\ ${ }^{1}$ National Technical University "Kharkiv Polytechnic Institute”, Frunze 21, UA-61002 Kharkiv, Ukraine \\ e-mail: tgbabak@gmail.com \\ ${ }^{2}$ Department of Energy, Power Engineering and Environment, Faculty of Mechanical Engineering and \\ Naval Architecture, University of Zagreb, Ivana Lučića 5, HR-10002 Zagreb, Croatia \\ e-mail: neven.duic@fsb.hr \\ ${ }^{3}$ National Technical University “Kharkiv Polytechnic Institute”, Frunze 21, UA-61002 Kharkiv, Ukraine \\ e-mail: gennadiy.khavin@mail.ru \\ ${ }^{4}$ Department of Energy, Power Engineering and Environment, Faculty of Mechanical Engineering and \\ Naval Architecture, University of Zagreb, Ivana Lučića 5, HR-10002 Zagreb, Croatia \\ e-mail: stas.boldyryev@ fsb.hr \\ ${ }^{5}$ Department of Energy, Power Engineering and Environment, Faculty of Mechanical Engineering and \\ Naval Architecture, University of Zagreb, Ivana Lučića 5, HR-10002 Zagreb, Croatia \\ e-mail: goran.krajacic@fsb.hr
}

Cite as: Babak, T., Duić, N., Possibility of Heat Pump use in Hot Water Supply Systems, J. sustain. dev. energy water environ. syst., 4(3), pp 203-215, 2016, DOI: http://dx.doi.org/10.13044/j.sdewes.2016.04.0017

\begin{abstract}
The problem of modernization of the heat module with two-stage mixing scheme connection of hot water supply by installations of the heat pump during interheating period is considered. Heating water of the in-house circuit of the building heating system is used as a heat source for heat pump. The district cooling of the residential areas is possible through the heaters during the summer. R600 refrigerant is chosen for heat pump for its environmental-friendliness and low-pressure of evaporation and condensation. The economic calculation is made for interheating period comparing the operation with and without heat pump. This paper advances selection of optimum amount of heat to be recovered during low potential heat utilisation and targets for heating and cooling capacities.
\end{abstract}

\section{KEYWORDS}

Hot water supply, Heat pump, Heat module, Interheating period.

\section{INTRODUCTION}

In recent years the steep rise of energy prices as well as the necessity to reduce carbon dioxide emissions, have intensified the research to improve the energy efficiency [1]. One of the most efficient methods for utilization of low potential heat, by elevating its thermal level, are compression heat pumps, which are well described in literature [2, 3].

Some studies consider reservoirs that may offer energy savings because their water is usually at a higher temperature in winter and lower temperature in summer than ambient air [4]. It assesses whether thermal energy stored in the reservoirs can be used as heat source for heat pump systems. Ground-source heat pump systems offer bigger advantages over traditional heating and cooling systems. However, their applications are limited due to the high initial costs of borehole drilling. In [5] the way to avoid these costs by reducing the size of the borefield is presented, e.g. by combining the system with other renewable energy sources or by using active regeneration to increase the system

\footnotetext{
* Corresponding author
} 
efficiency. The borefield is split into a warm part and a cold part, which allows for seasonal thermal-energy storage.

Plate heat exchangers are now widely being used in industrial installations because of their unique characteristics that are of interest and importance for process engineering. Recently the use of plate heat exchangers for heat pumps has increased. Natural refrigerants such as hydrocarbons, ammonia and carbon dioxide have specific features for use in heat pumps with compression [6]. Plate heat exchangers are advantageous in units coupled with evaporators and condensers. The proper selection of materials of plate is considered, taking into account the nature of the source of low potential heat for units coupled with evaporators. For units coupled with condenser the important thing is the proper prediction of fouling factor [7]. The typical duties of plate heat exchangers in heat pumps with natural refrigerants are defined and acceptable types of plate heat exchangers for each duty are discussed.

The emergence of industrially produced heat pumps has naturally shaped the possibility of their use in Hot Water Supply system (HWS) in tenement houses. In this case, the problem is not to replace the Central Heating Module (CHM) or Individual Heating Module (IHM), but their modernization.

One promising area in modernization is an enhanced design Heat Pump (HP) unit that supplies hot water to consumers during the interheating period. This approach makes possible to fully or partially disable the system of hot water heating network with a complete stoppage of the district boilers or heating network for this period.

At the present time the overwhelming majority of Heating Modules (HM) are equipped with two-stage mixed scheme connection of HWS to district heating network. Over the past 15 years the majority of shell and tube heat exchangers have been replaced with plate ones, which not only increased efficiency, but also freed up production space of heating modules. The possibility to use HP in the hot water system for residential multistorey buildings and other fields/areas have been considered by domestic researchers back in the 90's [8,9]. The idea of using the heating system as a carrier, apparently, was initially proposed in [10]. Mentioned circumstances could not lead to the idea of using the existing HM equipment as elements of a heat pump for hot water production in the interheating period. As you know, HM includes the evaporator and condenser, as well as heat exchanger of heating system and heat exchangers of 1 and 2 stages of the mixed scheme of hot tap water. Therefore, it brings up a question of possible use of HM heat exchangers in the equipment of the heat pump. This would allow the use of those devices for the interheating period, reduce the HP installation capital cost and partly abandon the network carrier for water heating. The case study was calculated for Ukraine's Kharkov city and Kharkov region with the prices of 2013.

There are inevitable technical and economic barriers in the path of practical implementation and realization of these projects, namely:

- The absence of physical source of heat for the HP of required power/capacity;

- Present off-the-shelf HM plate heat exchangers, produced by various manufacturers, are not unified;

- Quite high water temperature $\left(55-60{ }^{\circ} \mathrm{C}\right)$;

- Lack of a legislative framework for HP installation in the heat modules;

- Real economic justification for the use of HP in the HM;

- Unstable working of HP under uneven hot water hour-load conditions;

- Noisy HP operation, when installed in the basement of the building.

There are some heat sources for HP that provide high heat load of HWS vertical boreholes or energy piles as commonly used now. Nevertheless, the horizontal ground heat exchanger could be fitted under the basement of the building in the soil which has 
constant temperature during the year, the building heating system water itself also can be used a source of heat. Horizontal ground heat exchangers are most promising to design during the construction phase of apartment building, especially if it is equipped with basement car parking. For existing buildings horizontal ground heat exchanger unit is quite problematic, because of existing heating and hot water communications, ventilation, sanitation, electricity and gas. Technically, this problem can be solved, but it requires large capital investments and significant advance preparation.

There are several main issues of HP installation along with heating and hot water HM: technical implementation; high-quality, trouble-free operation and cost efficiency.

In other words, how to technically install HP on the already existing heating module, whether it will perform its functions well enough, how economically sound it could be and what would be the payback period for capital costs. The subject of this paper is an attempt to calculate, analyze and find the proposed HP installation approach.

The main objective of this article is to show the possibility of use of the heating system in the apartment building for air conditioning during the summer and at the same time to use, as much as possible, existing equipment of heating and hot water supply unit. Of course, practical implementation requires a detailed feasibility study from an economical point of view. However, this should be done on a case-by-case basis for a specific project. This article addresses the possibility to implement the solution in principle.

\section{METHODOLOGY}

The heating system during interheating period usually stays filled with a carrier that has room temperature. Moreover, in summer most rooms require some cooling during the day time, which currently is implemented through ventilation system and local air conditioning. The basic hot water consumption also takes place during the day. Heating water in the heaters would allow to cool rooms and use heated water in the HM. In fact, in the interheating period we could have double benefit - supply hot water by cooling consumers' apartments in the daytime. The main limitations here, apparently, are the following ones: indoor temperature should not fall below the statutory comfortable level at the any time during the period when the heating is off. If we take the lower limit of the room temperature as $20^{\circ} \mathrm{C}$, the use of the heating system carrier during April - May and September - October doesn't look possible. As the outside temperature rises the indoor temperature rises too that makes it possible to use the heating water as a heat source for $\mathrm{HP}$ and cooling. Based on the average outdoor temperatures in the European part of Russia and Ukraine, HP can work effectively starting from mid-May to mid-September, i.e. operation time of HP reduces from a 6 month interheating period to 3-4 months. During this period, water from the heating system can be expected from $24{ }^{\circ} \mathrm{C}$ to $20^{\circ} \mathrm{C}$ in May - July and August - September and from $28{ }^{\circ} \mathrm{C}$ to $24{ }^{\circ} \mathrm{C}$ in July and August. Furthermore, the heating system works due to the forced pump circulation of the carrier used to overcome the piping and radiator pressure drop. The average resistance of the standard residential building is estimated at $20-40 \mathrm{kPa}$ depending on the number of floors.

However, during the operation due to deposits in pipes and heating devices, flow resistance increases and in some cases can be redistributed between the branches and standpipes of the heating system. The latter fact may lead to overcooling of some rooms and overheating of others during the interheating period. A similar situation could take place when the heating system is used and can be corrected by hydraulic balancing of fouling in heating system. 
The majority of plate heat exchangers installed on CHM and IHM are gasketed units from different manufacturers. Despite the fact that those units are more expensive than brazed units, they allow mechanical cleaning of heat exchanger surface from dirt and deposits, and virtually restore them to original factory specifications. Operational pressure limit of up to $1.6 \mathrm{MPa}$ can be considered as a restriction of these units' vs. brazed ones. In addition, grouping of gasketed PHE evaporators and condensers in the HP system must contain only identical channels and the use of hydraulic channels with different resistances is not allowed. In addition, the plate evaporator and condenser design assumes that for correct unit grouping there should be one channel more on the cold side than on the hot side. This rule is due to reduction of the heat loss in the marginal system channels, but, in principle, but it's not mandatory and can be ignored. Plate core can also be rearranged by the adding or removing of some plates while cleaning PHE after the heating period. There are two selection criteria for HM heat exchangers that must work during the heating period:

- The original design before the construction;

- Modernization of the heat substation by installing a heat pump.

The latter task appears to be more difficult because, in fact, each building or group of buildings is unique and require individual design, which may include and change the grouping and capacity of the PHEs. Another one important issue for operation of HWS systems is sanitary norms, which have to be respected. The risk of Legionella infection is the same as in usual DH and HWS systems and the same methods of prevention can be used.

One of the main difficulties in connecting HP to HWS is quite strong requirement for water temperature $\left(55-60^{\circ} \mathrm{C}\right)$. Before actual use, hot water is usually mixed with cold water to provide comfortable temperature for a consumer. Historically, such high temperature was adopted by sanitary code and for the heating purposes of various utility in non residential buildings. Thus, the main use of high temperature is during the heating period. For the interheating period warming of these rooms is not required and, therefore, the output temperature could be reduced to $40-45{ }^{\circ} \mathrm{C}$. Such reduction in the end temperature of the hot water actually means that the cold water, that is mixed with the hot water during the heating period, should be heated to the hot water temperature about $40{ }^{\circ} \mathrm{C}$ by the heat pump. Only in this case the maximum daily consumption of hot water can be provided.

Another possibility to ensure the target temperature of $55-60{ }^{\circ} \mathrm{C}$ could be the use of a heat exchanger from the first stage of the HM as a post-HP water heater. This allows reducing the required power of the HP, though without complete rejection of the network water. Apparently, any implementation scheme that ensures uninterrupted operation of the HWS and is economically justified can be used in each particular case.

Stable HP operation under condition of uneven daily hot water consumption is mainly determined by the stability of the compressor work load without tank-batteries. Installed storage tanks essentially flatten peaks in hot water demand and provide sufficiently constant load on the heat pump. Noiselessness of the TP installed in the basement is determined by the noiselessness of the compressor itself and the carrier flow rate through the pipes. These factors should be considered and taken into account for correct HP design and proper equipment selection. The size of system is based on heat duty of HWS and district heating and the heat load and dimensions of the heat pump also depends on system size.

It is proposed to implement two integration options of heat pump with heating and hot water module. The first one involves the installation of a module, which includes the heating unit and a heat exchanger of $1^{\text {st }}$ stage of hot water. These heat exchangers are not 
operated during interheating period now. This retrofit is real for individual heat substations, which have a free space by substitution shell and tube heat exchangers to plate ones. The second option provides direct integration of heat pump to DH and HWS module. In this case, the module needs to be completely retrofitted. Equipment of heat pump is added as well as new regulation system and control valves. Currently, concepts were developed for both approaches. However, the pilot unit was not operated yet and it is under development and testing.

\section{CASE STUDY}

Let's consider the most common and typical HM with two-stage mixing scheme connection of HWS system with gasketed plate heat exchangers, Figure 1.

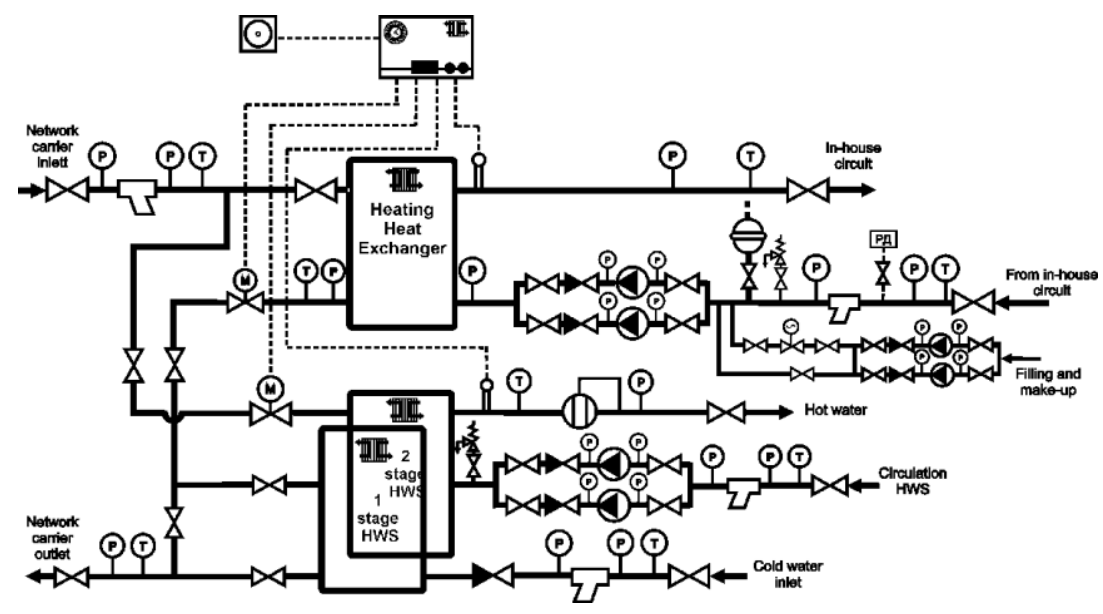

Figure 1. Basic circuit of heating module with two-stage mixed scheme connection of HWS to district heating network

The calculations below are for a module with the following conditions. The maximum load of the heating system is $Q_{\text {heat }}=545.6 \mathrm{~kW}$, maximum HWS heat load is $Q_{H W S}=541.7 \mathrm{~kW}$. Data for calculation of heating plate heat exchanger were preset to the following. Inlet temperature of the network carrier: $130{ }^{\circ} \mathrm{C}$, outlet: $76{ }^{\circ} \mathrm{C}$; temperature of the in-house circuit water input: $95^{\circ} \mathrm{C}$, output: $70{ }^{\circ} \mathrm{C}$. Heating water flow rate $\left(\mathrm{m}^{3} / \mathrm{h}\right)$ for network: 9.2, in-house: 19.2. Allowable pressure drop for the network carrier: $20 \mathrm{kPa}$, for in-house: $40 \mathrm{kPa}$. Data for calculating of the heat exchangers of the two-stage mixed scheme were preset to the following. Network inlet temperature: $70^{\circ} \mathrm{C}$, outlet: $30^{\circ} \mathrm{C}$; hot water inlet temperature: $5{ }^{\circ} \mathrm{C}$, outlet: $60{ }^{\circ} \mathrm{C}$. Carriers flow rate $\left(\mathrm{m}^{3} / \mathrm{h}\right)$ for network: 8.0 , maximum hot water flow rate: 8.5. Allowable pressure drop for the network carrier: $50 \mathrm{kPa}$, for in-house: $30 \mathrm{kPa}$. Margin for plate heat exchanger calculation is no less $30 \%$.

As a result of calculation (using plate heat exchangers for HP), "Alfa Laval" heat exchanger type M6 was chosen for installation. Characteristics for these units are shown in the Table 1. Total cost of heating and HWS plate heat exchangers is $39 \%$ of full cost of HM including transportation, assembling and phasing-in costs.

Table 1. "Alfa Laval" plate heat exchangers type M6 chosen for installation in the HM

\begin{tabular}{cccc}
\hline Position & Heat load $[\mathrm{kW}]$ & Heat exchanger surface $\left[\mathrm{m}^{2}\right]$ & Grouping \\
\hline Heating & 545.6 & 8.7 & $1 \times 29 \mathrm{H} / 1 \times 30 \mathrm{H}$ \\
$1^{\text {st }}$ stage & 346.6 & 9.3 & $1 \times 31 \mathrm{H} / 1 \times 32 \mathrm{H}$ \\
$2^{\text {nd }}$ stage & 195.1 & 5.1 & $1 \times 17 \mathrm{H} / 1 \times 18 \mathrm{H}$ \\
\hline
\end{tabular}


A two-stage mixed scheme is most often used for hot water. It consists of two heat exchangers of the $1^{\text {st }}$ stage, where tap water is preheated to $20-30^{\circ} \mathrm{C}$ by return water from the heating system of the building mixed with water from a heat exchanger of the second stage. Then finally heated water is raised to a temperature of $55-60{ }^{\circ} \mathrm{C}$ in the heat exchanger stage 2 . This scheme brings significant savings of HWS but it can be applied only during the heating season.

\section{Daily load HWS and hourly load calculation}

Hot water consumption has a pronounced unevenness by hour of the day and day of the week. Typical change of water flow $G_{\mathrm{HWS}}^{\mathrm{i}} / G_{\mathrm{HWS}}^{\mathrm{max}}$ by hour of the day is shown in Figure 2. A characteristic feature of water consumption graphs is the presence of general regularities of the draw by hour of the day with a sharp irregularity within days. There are two peaks: from 7:00 to 10:00 in the morning, and from 18:00 to 23:00 in the evening.

According to $[11,12]$ during evening peak hours water consumption can be above the weekdays average by 2.2-2.4 times, and on Sundays - by 2.6-2.8 times.

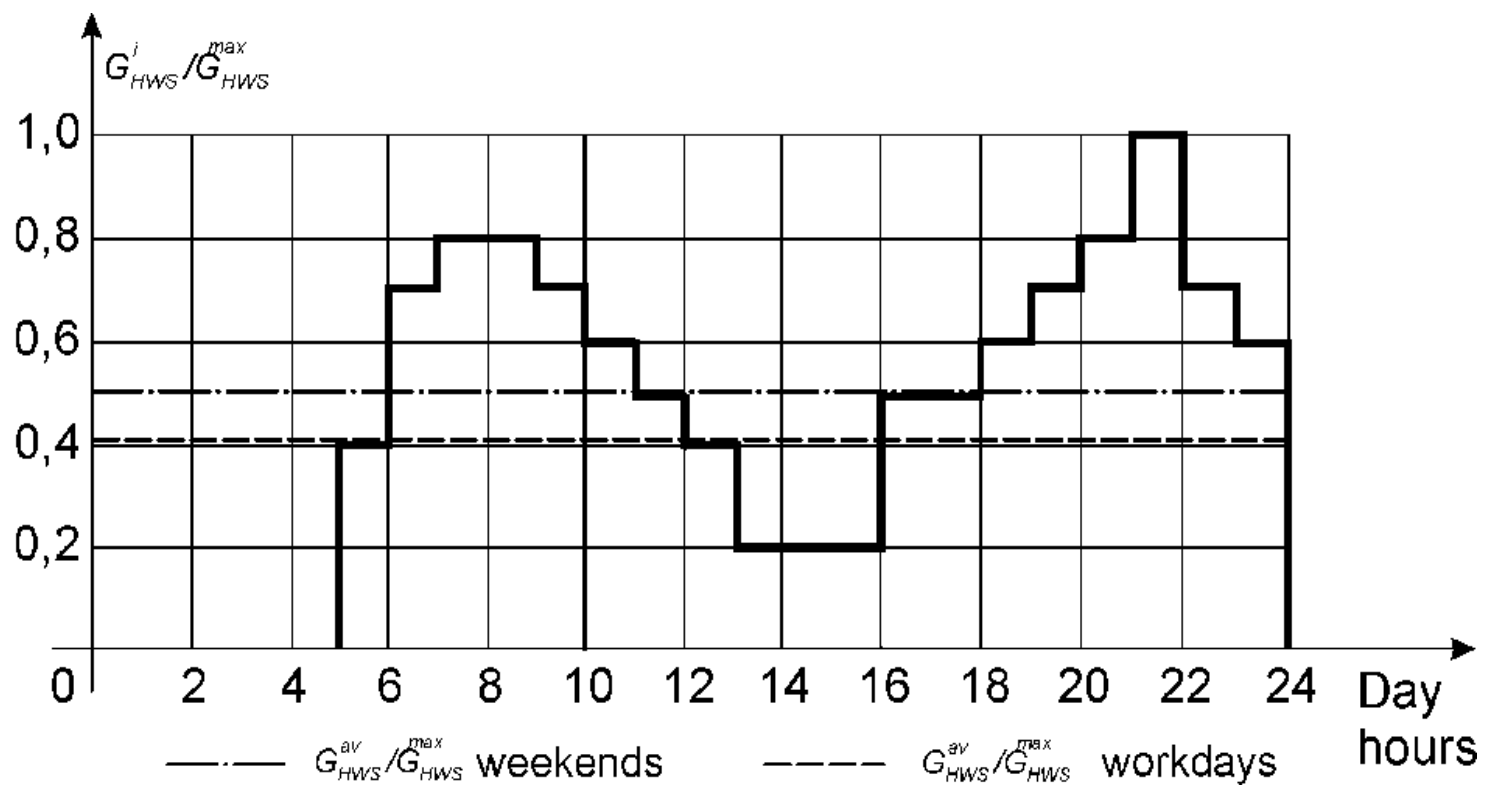

Figure 2. Average graph of hot water consumption change

Table 2 and 3 show average values of hourly consumption of hot water, and the total pressure drops when pumping the heated water through the network with two-stage scheme of hot water heat exchangers. The average value of daily irregularity is set to 0.91 on weekdays and to 1.22 on weekend relative to the average value for the week. The studies presented in [13] have shown that the greatest flow rate of hot water is observed in the holidays. Let's also assume that during the interheating period temperature of tap water for heating on average is $t_{\mathrm{w} \_ \text {in }}=15^{\circ} \mathrm{C}$, the temperature of heating devices in the rooms cannot fall below $t_{\text {in }}=20{ }^{\circ} \mathrm{C}$. The average cost per $1 \mathrm{Gcal}(1.613 \mathrm{MWh})$ is 750 Ukrainian Hryvnas (UAH). The average cost of $1 \mathrm{kWh}$ of electricity is UAH 0.75 . All the prices provide for 2013 and UAH 1 is EUR 0.095 [14]. The total hot water daily consumption shown in Figure 2 is:

$$
G_{\mathrm{HWS}}^{\text {day }}=G_{\mathrm{HWS}}^{\max } \sum_{i=1}^{24} g_{\mathrm{i}} \Delta t_{\mathrm{i}} \approx 10.9 G_{\mathrm{HWS}}^{\max }
$$


and for the maximum demand flow rate of $8.5 \mathrm{~m}^{3} / \mathrm{h}$ daily heat consumption is $4.169 \mathrm{Gcal}$ $(6.725 \mathrm{MWh})$ and daily cost for the heat is $C_{\mathrm{net}}=3,127 \mathrm{UAH} /$ day. $G_{\mathrm{HWS}}^{\text {day }}$ is the total daily consumption of hot water from maximum heat load of HWS.

Another article in operation costs is the cost of electricity for pumping cold and hot carrier through the heat exchangers. The calculation of these costs is based on the average HWS water consumption:

$$
G_{\mathrm{HWS}}^{\mathrm{aw}}=G_{\mathrm{HWS}}^{\mathrm{day}} / 19=4.88 \mathrm{~m}^{3} / \mathrm{h}
$$

where $G_{\mathrm{HWS}}^{\mathrm{aw}}$ is average hourly consumption of hot water, and 19 is total operating time of HWS during the day.

And network water:

$$
G_{\text {net }}^{\text {av }}=G_{\text {net }}^{\text {day }} / 19=4.59 \mathrm{~m}^{3} / \mathrm{h}
$$

The pressure drops calculated for the average flow rate in the heat exchangers of both stages are on the network carrier $\Delta p_{\mathrm{h}}=8.7 \mathrm{kPa}$ and heated water $\Delta p_{\mathrm{c}}=9.4 \mathrm{kPa}$. Then the power required for pumping the carriers through the heat exchangers, will be:

$$
Q_{\text {pump }}=\left(G_{\mathrm{HWS}}^{\mathrm{av}} \Delta p_{\mathrm{c}} / \eta+G_{\text {net }}^{\mathrm{av}} \Delta p_{\mathrm{h}} / \eta\right) / 3.6 \approx 34 \mathrm{~W}
$$

where $\eta=0.7$ is average efficiency of installed pumps. Average daily cost of electricity for the pumps will be:

$$
C_{\text {pump }}=Q_{\text {pump }} \times 19 \times 0.75 \times 10^{-3} \approx 0.485 \mathrm{UAH} / \text { day }
$$

The calculation does not take into account the cost of tap water for heating. Assuming that interheating period duration is 180 days, including full 90 days of summer, taking 65 as average number of working days and 25 as weekend and holidays, the total operating cost expenses for HWS work for 3 months would be:

$$
C_{\text {all_net }}=\left(C_{\text {net }}+C_{\text {pump }}\right) 65 k_{\mathrm{hw}}+\left(C_{\text {net }}+C_{\text {pump }}\right) 25 k_{\mathrm{hs}} \approx 280,373 \mathrm{UAH}
$$

where $k_{\mathrm{hw}}=0.91$ is the average rate of flow during the week, and $k_{\mathrm{hs}}=1.22$ is the average rate increase of hot water on weekends and holidays. Thus, average cost of HWS working for 3 months interheating period will be UAH 280,373. The calculation assumed that the value of the maximum flow of hot water in winter and summer are same. Although it is obvious that the maximum and average flow rate in the summer is lower, due to vacations and stay home residents in the country. The latter fact plays an important role in selecting the heat pump.

Table 2. Average hourly consumption

\begin{tabular}{cccccccc}
\hline \multirow{2}{*}{ Parameter } & \multicolumn{7}{c}{ Ratio daily flow rate $g_{\mathrm{i}}=G_{\mathrm{HWS}}^{\mathrm{i}} / G_{\mathrm{HWS}}^{\mathrm{max}}$} \\
\cline { 2 - 9 } & 0.2 & 0.4 & 0.5 & 0.6 & 0.7 & 0.8 & 1.0 \\
\hline Flow rate $G_{\mathrm{HWS}}^{\mathrm{i}}\left[\mathrm{m}^{3} / \mathrm{h}\right]$ & 1.7 & 3.4 & 4.25 & 5.1 & 5.95 & 6.8 & 8.5 \\
Number hours in the day $\left[\Delta t_{\mathrm{i}}\right]$ & 3 & 2 & 3 & 3 & 4 & 3 & 1 \\
\hline
\end{tabular}


Table 3. Total pressure drop in the heat exchangers

\begin{tabular}{cccccccc}
\hline \multirow{2}{*}{ Parameter } & \multicolumn{6}{c}{ Ratio daily flow rate $g_{\mathrm{i}}=G_{\mathrm{HWS}}^{\mathrm{i}} / G_{\mathrm{HWS}}^{\mathrm{max}}$} \\
\cline { 2 - 8 } & 0.2 & 0.4 & 0.5 & 0.6 & 0.7 & 0.8 & 1.0 \\
\hline Total pressure drop $\Delta p_{\mathrm{HWS}}^{\mathrm{i}}[\mathrm{kPa}]$ & 2.2 & 9.1 & 15.2 & 19.1 & 26.2 & 33.7 & 53.3 \\
Ratio $\left[\Delta p_{\mathrm{HWS}}^{\mathrm{i}} / \Delta p_{\mathrm{HWS}}^{\mathrm{max}}\right]$ & 0.04 & 0.2 & 0.3 & 0.4 & 0.5 & 0.65 & 1 \\
\hline
\end{tabular}

\section{The selection of refrigerant}

As the refrigerant for HP it is proposed to use R600 or isobutene, which is natural gas that doesn't deplete the ozone layer $(\mathrm{ODP}=0)$ and does not contribute to greenhouse effect (HGWP $=0.001$ ). R600 gas is two times heavier than air. The mass of the refrigerant circulating in the refrigerant unit or HP, compared with R134a or R12 is about $30 \%$ less. R600 is highly soluble in oil and has a higher coefficient of performance than $\mathrm{R} 12$. The cooling specific amount of R600 is twice less than R12, which is compensated by the use of more powerful compressors. R600 operates at low pressure. The main drawback is that it is flammable and explosive when combined with air in the refrigerant volume fraction $1.3-8.5 \%$ (lower explosion limit $-31 \mathrm{~g} / \mathrm{m}^{3}$, the top $-205 \mathrm{~g} / \mathrm{m}^{3}$ ). The Table 4 shows the dependence of boiling point of R600 on pressure.

Last time the R600 is used more often in heat pumps. There are a numbers of recent publications that demonstrate the use of this refrigerant for design and application of different heat pumps [15]. In [16] the authors describe the economy of exploiting heat from low-temperature geothermal sources for high-temperature heating of buildings using a two stage heat pump with R600 as refrigerant for second stage. The application of R600a heat pump with cooling capacity $325 \mathrm{~kW}$ was done for a Danish hospital. Safety restrictions, such as flammability of hydrocarbon refrigerant can minimized with use of hermetic design with no shaft seals or semi-welded heat exchangers as mentioned in the case study (standard ISO817) [17].

European and international standards Amendment 1 to EC 60335-2-24, Ed.4 allowed the use flammable refrigerants (including isobutene) in domestic refrigerators. At the end of 2005, about $10 \%$ of all household refrigerators in the world and 35\% in Europe were working on the R600.

Table 4. Dependence of boiling point of R600 on pressure (gage pressure)

\begin{tabular}{ccccccccc}
\hline$T\left[{ }^{\circ} \mathrm{C}\right]$ & 0 & 10 & 20 & 30 & 40 & 50 & 60 & 70 \\
$p[$ bar $]$ & 0.57 & 1.21 & 2.02 & 3.05 & 4.32 & 5.86 & 7.72 & 9.91 \\
\hline
\end{tabular}

\section{Design and operation of heat exchangers}

The basic components of HP are:

- Evaporator;

- Condenser;

- Compressor;

- Control system;

- Reducing unit.

The heat exchanger of heating system is used as the evaporator, and exchanger stage 2 HWS system as the condenser. The plate heat exchanger of $1^{\text {st }}$ stage is used as a hot water heater, when HP power is not enough. The following data were used for calculating the HP evaporator: inlet R600 pressure 2.51-2.56 bar; temperature of the in-house circuit at 
the input of $t_{\text {in }}=20{ }^{\circ} \mathrm{C}$, output - from $21{ }^{\circ} \mathrm{C}$ to $26^{\circ} \mathrm{C}$; the maximum flow rate of R600 $1,390 \mathrm{~kg} / \mathrm{h}$ and of water-house circuit $-19.2 \mathrm{~m}^{3} / \mathrm{h}$. The following data were used for the calculation of condenser: R600 pressure at the inlet is 11.0 bar; temperature of hot water inlet $15{ }^{\circ} \mathrm{C}$, the outlet - depending on the load. The design load of HWS in the summer $Q_{\mathrm{HWS}}^{\max }=Q_{\mathrm{HWS}}^{\max } \times 4.1868 \times(60-15) / 3.6=444.8 \mathrm{~kW}$, where the water density is $1,000 \mathrm{~kg} / \mathrm{m}^{3}$. The water heating load in-house circuit (Table 2), $Q_{\text {bild }}=G_{\text {bild }} \times$ $4.1868 \times\left(t_{\text {out }}-t_{\text {in }}\right) / 3.6$.

Outlet temperature of the hot water from the condenser of the heat pump is a function of water temperature from rooms $t_{\text {out }}$. This temperature can be calculated approximately by the average amount of water flow to the HWS:

$$
G_{\mathrm{HWS}}^{\mathrm{av}}=G_{\mathrm{HWS}}^{\mathrm{day}} / 19=4.88 \mathrm{~m}^{3} / \mathrm{h}
$$

from relationship:

$$
t_{\text {out }}=\left(3.6 Q_{\mathrm{bild}}\right) /\left(4.1868 G_{\mathrm{HWS}}^{\mathrm{av}}\right)+t_{\mathrm{w}_{-} \text {in }}
$$

Eq. (8) calculates the return temperature of heat carrier (hot water), which goes back from the building. In this case there is a need to heat the water to the required $55-60{ }^{\circ} \mathrm{C}$. This can be done using district network water in heat exchanger stage 1 that is used as a heater. In fact, in this configuration, the HP plays a similar function to the return water from heating system for two-stage mixed scheme when it operates during heating season. The cost of water network can be calculated using equation:

$$
C_{\text {net_hp }}=10.9 G_{\mathrm{HWS}}^{\max }\left(60-t_{\text {out }}\right) \times 10^{-3} \times 750 \mathrm{UAH} / \text { day }
$$

Eq. (9) calculates of net water price. This water is used for HWS needs and is heated up to $60{ }^{\circ} \mathrm{C}$ while the price of $1 \mathrm{Gcal}(1.613 \mathrm{MWh})$ of heat energy is UAH 750 . Total average pressure drops in heat exchangers, when using in HP, are considered constant and equal to the following. In the evaporator: the refrigerant side $-41.4 \mathrm{kPa}$, the water $10.0 \mathrm{kPa}$; in the condenser: the refrigerant side $-0.6 \mathrm{kPa}$, the water $-4.0 \mathrm{kPa}$; in the heater: on network carrier $-0.5 \mathrm{kPa}$, over hot water $-1.0 \mathrm{kPa}$. The pressure drop on in-house circuit while pumping heated water is set to $20 \mathrm{kPa}$. The cost of electricity for pumping cold and hot carriers through the heat exchangers and in-house heating system:

$$
\begin{aligned}
C_{\text {pump_hp }}=( & \left.G_{\mathrm{HWS}}^{\mathrm{av}} \Delta p_{\mathrm{c}_{-} \mathrm{hp}} / \eta+G_{\text {net }}^{\mathrm{av}} \Delta p_{\mathrm{h}_{-} \mathrm{hp}} / \eta+G_{\mathrm{bild}} \Delta p_{\text {bild }} / \eta\right) / 3.6 \times 0.7 \times 19 \\
& \times 10^{-3} \approx 3.7 \mathrm{UAH} / \text { day }
\end{aligned}
$$

where:

- $\Delta p_{\mathrm{c} \_\mathrm{hp}}=42.5 \mathrm{kPa}$ is the total pressure drop in heat exchangers on the heated side;

- $\Delta p_{\mathrm{h} \_\mathrm{hp}}=15.0 \mathrm{kPa}$ is the total pressure drop in heat exchangers on the heating side;

- $\Delta p_{\text {bild }}=20 \mathrm{kPa}$ is the pressure drop in the building heating system.

Total operating costs for the system with a heat pump hot water would be:

$$
C_{\text {net_hp }}=\left(C_{\text {net_hp }}+C_{\text {pump_hp }}\right) 65 k_{\text {hw }}+\left(C_{\text {net_hp }}+C_{\text {pump_hp }}\right) 25 k_{\text {hs }} \mathrm{UAH}
$$

Eq. (10) and (11) are calculations of cost for pumping of heat carriers through the heating system of the building, heat exchangers and other devices. Then the saving is 
calculated taking into account 90 operating days in a year and 19 hours per day. We assumed that the production of $1 \mathrm{Gcal}(1.613 \mathrm{MWh})$ of heat in the heat pump consumes $0.33 \mathrm{MWh}$ of electricity to drive the compressor. Then, the total cost of the compressor provided $Q_{b i l d}$ that its load is 19 hours per day, 90 days a year:

$$
\begin{gathered}
C_{\text {com }}=Q_{\text {bild }} \times 19 \times 90 \times 750 \times 0.33 / 1,163 \mathrm{UAH} \\
\Delta C=C_{\text {net }}-C_{\text {net_hp }}-C_{\text {com }}
\end{gathered}
$$

The operation of the HP with two-stage mixing scheme HWS within 3 months, saves money in the interheating period. The chart, which demonstrates the savings depending on outside temperature, is provided. Dependency of $\Delta C$ on the temperature of the water coming out of the heating system is shown in Figure 3. The substation starts to work in cooling mode only if the average daily temperature in the building is at a certain level, which is unique for each region. Automation devices installed in the observed module can regulate this.

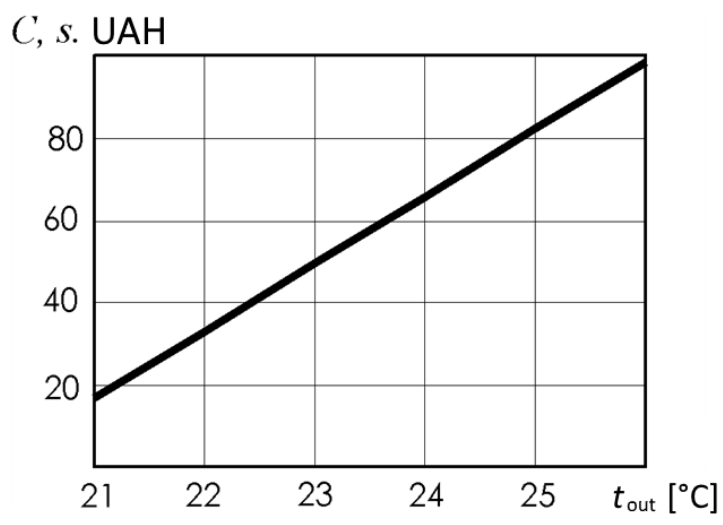

Figure 3. The relationship between the differences of total cost of ownership of domestic hot water without using HP and with HP on water temperature heating circuit

The graph shows that even with heating circuit water only to $22{ }^{\circ} \mathrm{C}$, the savings can reach about 33 thousands UAH for 3 months in the summer. These do not include:

- Heat loss during transport and operation of all equipment;

- Reduce the average daily consumption of hot water in summer;

- Increase in temperature of hot water in the summer above $15^{\circ} \mathrm{C}$ by reducing cooling and circulation;

- Cost of make-up water in the heating system;

- Cost savings due to reduced energy consumption for cooling of rooms.

\section{CONCLUSION}

The possibility of heat pump use in the heating system of residential high-rise building with the building heating system as a heat source in interheating period is considered. It is shown that installed HP in the HM with two-stage mixing scheme connection HWS system using the existing heat exchangers can give an average saving of up to 100 thousand UAH.

Savings are achieved due to reduction of network water consumption and district cooling. Additional requirements to upgrade through the allocation of additional areas, pumping and control equipment are not established. 
Almost all residential buildings connected to the district heating and that have heat module with two-stage mixing scheme HWS system have market potential. Climatic conditions for such modernization are quite broad and include virtually all residential buildings in Europe. Primary energy consumption is taking place during daytime, when the cost is high. And so a promising direction of development of the proposed approach is to use HP in the in the heating system with hot water supply tanks, which are charged at night.

The potential future work will be focused on more practical aspects of concept implementation such as optimal design and operation of heating and cooling systems, refrigerant selection with higher thermal performance, etc.

The results of this work may be used also in Total Site methodology development allowing heat recovery for district heating needs of both new designs and as retrofits to existing sites to ensure fast, widespread and cost-efficient industrial deployment. It leads to carbon footprint reduction and energy efficiency improvement of regions with heating and cooling demands during winter and summer operation modes.

\section{ACKNOWLEDGMENTS}

This work is supported by European Commission seventh Programmed managed by REA - Research Executive Agency, http://ec.europa/rea (FP7/2007-2013) under Grant agreement PIRSES-GA-2011-294933 (DISKNET project) and by the EC and Croatian Ministry of Science Education and Sports under project "CARBEN" (NEWFELPRO Grant Agreement No. 39).

\section{NOMENCLATURE}

$\mathrm{UAH}$

Call_net

$C_{\text {com }}$

$\mathrm{C}_{\text {net }}$

$C_{\text {net_hp }}$

$C_{\text {pump }}$

$C_{\text {pump_hp }}$

$G_{\text {build }}$

$G_{\text {HWS }}^{\text {av }}$

$G_{\text {HWS }}^{\text {day }}$

$G_{\text {HWS }}^{\mathrm{i}}$

$G_{\mathrm{HWS}}^{\max }$

$G_{\text {net }}^{\text {av }}$

$G_{\text {net }}^{\text {day }}$

$g_{\mathrm{i}}=G_{\mathrm{HWS}}^{\mathrm{i}} / G_{\mathrm{HWS}}^{\max }$

$k_{\mathrm{hs}}$

$k_{\text {hw }}$

$Q_{\text {build }}$

$Q_{\text {heat }}$
Ukrainian Hryvna, the currency of Ukraine total operating cost expenses for HWS work by 3 months the total cost of the compressor provided $Q_{\text {bild }}$ that its load is 19 hours per day, 90 days a year daily cost of the heat

cost of water network with HP average daily cost of electricity for the pumps cost of electricity for pumping cold and hot carriers through the heat exchangers and in-house heating system

the flow rate of water in the build

average flow rate of hot water

daily flow rate of hot water

current flow rate of hot water

max flow rate of hot water

average flow rate of network hot water

full flow rate per day of network hot water

average flow rate increase of hot water during weekends and holidays

average flow rate during the week

load of hot tap water

max heat load of heating system
$[€]$

$[€]$

$[€ /$ day $]$

$[€]$

$[€]$

$[€]$

[kg/hour] or $[\mathrm{kg} / \mathrm{s}]$

$[\mathrm{kg} / \mathrm{hour}]$ or $[\mathrm{kg} / \mathrm{s}]$

$[\mathrm{kg} / \mathrm{hour}]$ or $[\mathrm{kg} / \mathrm{s}]$

$[\mathrm{kg} / \mathrm{hour}]$ or $[\mathrm{kg} / \mathrm{s}]$

$[\mathrm{kg} / \mathrm{hour}]$ or $[\mathrm{kg} / \mathrm{s}]$

$[\mathrm{kg} / \mathrm{hour}]$ or $[\mathrm{kg} / \mathrm{s}]$

$[\mathrm{kg} / \mathrm{hour}]$ or $[\mathrm{kg} / \mathrm{s}]$ 


\begin{tabular}{|c|c|c|}
\hline$Q_{\text {hws }}$ & max heat load of hot tap water & {$[\mathrm{kW}]$ or } \\
\hline$Q_{\text {pump }}$ & $\begin{array}{l}\text { power required for pumping the carriers } \\
\text { through the heat exchangers }\end{array}$ & \\
\hline$t_{\text {in }}$ & temperature of heating devices in the rooms & \\
\hline$t_{\text {out }}$ & water temperature from rooms & {$\left[{ }^{\circ} \mathrm{C}\right.$} \\
\hline$t_{\mathrm{w}_{-} \text {in }}$ & $\begin{array}{l}\text { average temperature of tap water for heating } \\
\text { during the interheating period }\end{array}$ & \\
\hline$\Delta C$ & $\begin{array}{l}\text { the differences of total cost of ownership of } \\
\text { domestic hot water without using HP and with } \\
\text { HP }\end{array}$ & \\
\hline$\Delta p_{\text {bild }}$ & $\begin{array}{l}\text { the pressure drop in the building heating } \\
\text { system }\end{array}$ & \\
\hline$\Delta p_{\mathrm{c}}$ & pressure drop of heated water & \\
\hline$\Delta p_{\mathrm{h}}$ & pressure drop of network carrier & \\
\hline$\Delta p_{\text {c_hp }}$ & $\begin{array}{l}\text { the total pressure drop in heat exchangers on } \\
\text { the heating side }\end{array}$ & \\
\hline$\Delta p_{\mathrm{h} \_\mathrm{hp}}$ & $\begin{array}{l}\text { the total pressure drop in heat exchangers on } \\
\text { the heated side }\end{array}$ & \\
\hline$\Delta p_{\mathrm{HWS}}^{\mathrm{i}}$ & current pressure drop in hot tap water system & \\
\hline$\Delta p_{\mathrm{HWS}}^{\max }$ & max pressure drop in hot tap water system & \\
\hline
\end{tabular}

\section{Greek letters}

$\eta$

average efficiency of installed pumps

\section{REFERENCES}

1. Klemeš, J., Friedler, F., Bulatov, I. and Varbanov, P., Sustainability in the Process Industry: Integration and Optimization, McGraw-Hill, New York, USA, 2010.

2. Poulet, P. and Outbib, R. Energy Production for Dwellings by using Hybrid Systems based on Heat Pump Variable Input Power, Applied Energy, Vol. 147, pp 413-429, 2015, http://dx.doi.org/10.1016/j.apenergy.2015.03.005

3. Junghans, L., Evaluation of the Economic and Environmental Feasibility of Heat Pump Systems in Residential Buildings, with Varying Qualities of the Building Envelope, Renewable Energy, Vol. 76, pp 699-705, 2015, http://dx.doi.org/10.1016/j.renene.2014.11.037

4. Kindaichi, S., Nishina, D., Wen, L. and Kannaka T., Potential for using Water Reservoirs as Heat Sources in Heat Pump Systems, Applied Thermal Engineering, Vol. 76, pp 47-53, 2015, http://dx.doi.org/10.1016/j.applthermaleng.2014.10.091

5. Allaerts, K., Coomans, M. and Salenbien R., Hybrid Ground-source Heat Pump System with Active Air Source Regeneration, Energy Conversion and Management, Vol. 90, pp 230-237, 2015, http://dx.doi.org/10.1016/j.enconman.2014.11.009

6. Thonon, B. and Bontemps, A., Condensation of Pure and Mixture of Hydrocarbons in a Compact Heat Exchanger: Experiments and Modelling, Heat transfer Engineering, Vol. 23, No. 6, pp 3-17, 2002, http://dx.doi.org/10.1080/01457630290098718

7. Stenhade, C., A Technical Reference Manual for Plate Heat Exchangers in Refrigeration and Air Conditioning Applications, Alfa Laval Thermal, $3^{\text {rd }}$ ed., Sweden, Lund, 1998.

8. Gidowich, I. C. and Trutaev, V. I. The Systematic Approach to Evaluate of Heat Pump Effectiveness (in Russian), Heat supply news, No. 11, pp 44-49, 2001.

9. Smirnova, E. G. and Trosteneskyy, L. M., The Heat Engineering Analysis of Joint Work Existing Heating Systems and Heat Pumps (in Russian), Industrial heat engineering, Vol. 20, No. 3, pp 38-41, 1998. 
10.Energy Saving in Buildings, Special Edition for Possibility of Heat Pumps Use (in Russian), No. 4, Kiev, 1997.

11.Chisniakov, N. N., Grudsinskyy, M. M. and Livchak, V. I., Growth of Effectiveness Hot Water Supply System Working (in Russian), Stroiizdat, Moscow, 1988.

12.Bogoslovskyy, V. N., Krupnov, B. A. and Skanavi, A.N., Inner Sanitary Structures, Part 2: Water Supply and Sewerage (in Russian), 1990.

13.Pavlov, I. I. and Phedorov, M. N., Boiler Installation and Heat Networks (in Russian), Stroiizdat, Moscow, 1986.

14.www.xe.com/currencycharts/?from $=U A H \&$ to $=E U R \& v i e w=5 Y$,

[Accessed: 15-September-2015]

15.Zakula, T., Armstrong, P. and Norford, L., Optimal Coordination of Heat Pump Compressor and Fan Speeds and Subcooling over a Wide Range of Loads and Conditions, HVAC and $R$ Research, Vol. 18, No. 6, pp 1153-1167, 2012, http://dx.doi.org/10.1080/10789669.2012.713832

16.Kulcar, B., Goricanec, D. and Krope, J., Economy of exploiting Heat from Low-temperature Geothermal Sources using a Heat Pump, Energy and Buildings, Vol. 40, No. 3, pp 323-329, 2008, http://dx.doi.org/10.1016/j.enbuild.2007.02.033

17.Experience with R600a heat pumps installed at Danish hospital, http://www.hydrocarbons21.com/articles/2782/experience_with_r600a_heat_pumps_in stalled_at_danish_hospital, [Accessed: 25-October-2015] 